石油技術協会誌 第 68 巻 第 6 号 (平成15年11月)

JOURNAL OF THE JAPANESE ASSOCIATION FOR PETROLEUM TECHNOLOGY

VOL. 68 , NO. 6 (Nov., 2003)

報 告

\title{
ガス需要および新ガス製品に関する市場性*
}

\author{
中 村 新**
}

(Received September 3, 2003 ; accepted November 12, 2003)

\section{Overview of the gas demand and the potential market of gas-base liquid fuels}

\begin{abstract}
Arata Nakamura
Abstract: Natural gas and gas-base liquid fuels such as FT (Fischer-Tropsch) Diesel are expected as clean fuels. Natural gas consumption is evaluated to be increasing rapidly within next 30 years. Now, a lot of changes are observed in natural gas and LNG trade and the competition in the gas trade is coming to severe. But, because a large investment is required for LNG project and pipeline project, sharing of risk and profit and cooperative competition between suppliers and buyers are important to stably supply enough natural gas to the market.

Conversion of natural gas to liquid transportation fuels and other specialty products is seen as a potentially attractive means of monetizing "stranded" gas. A large number of potential commercial-scale GTL (gas-to-liquid) projects are now being planned with a capacity totaling 1.6 -1.8 MMBPD. Based on the market studies, it was evaluated that there are potential markets for GTL products, especially FT Diesel and FT Naphtha, and that timing of the start-up and further cost reduction are keys to successfully introduce these products to the market.
\end{abstract}

Key words: natural gas, stranded gas, LNG, gas-to-liquid (GTL), Dimethyl Ether (DME), marketability

\section{1.はじめに}

天然ガスは，その埋蔵量が豊富であることやクリーン なエネルギーであることから，近年注目を浴びており， その需要は今後も大幅な伸びが予想されている。また, 豊富な天然ガス資源の有効利用の手段として, 天然ガス を液体燃料に転換して利用しょうとする GTL（Gas-To-Liquid）の商業化プロジェクトが盛んに検討されて いる。

ここでは，まず天然ガス需給動向に関し LNG を中心

* 平成15年 6 月 25 日, 平成 15 年度石油技術協会春季講演会 開 発・生産部門シンポジゥム「ガス開発ビジネスと技術課題」

で講演 This paper was presented at the 2003 JAPT Development and Production Symposium entitled "Gas Development Business and Technical Challenges", held in Makuhari, Chiba, Japan, June 25, 2003.

**石油公団 Japan National Oil Corporation

Copyright (C) 2003, JAPT
に現状および今後について概観し，その後，新たな燃料 として期待される天然ガス液体化燃料（GTL 合成油, ジメチルエーテル（DME）など）に関し，現在の世界 における開発動向, 市場性, 今後の課題などについて考 察する。

\section{2. 天然ガスの需給動向}

\section{1 天然ガスを取り巻く環境}

2001年末時点の天然ガスの確認埋蔵量は，BP統計に よれば $5,477 \mathrm{~T} \mathrm{cf}$ であり, 可採年数 $(\mathrm{R} / \mathrm{P})$ は 61.9 年で ある。2003年 6 月に開催された世界ガス会議東京大会で は, 最新の評価として天然ガスの可採年数が約 67 年, 石 油が約42年との評価が紹介された。

天然ガスは，石油に比べて埋蔵量は豊富にあるもの の, その多くが中東や旧ソ連地域の大規模ガス田に賦存 しており，その輸送手段が現状パイプラインと LNGに 限られていることから，供給源から経済的に供給できる 
範囲は限られており，地域的な需給バランスには石油以 上に大きな差が見られる。その結果, 大規模なガス田が その十分な市場を確保することに苦労している一方で, 高い輸送費を払って遠方の供給源からガスを導入するこ とが必要な地域も見られる。

またガス田の規模を考えると，世界のガス田の半分以 上が $1 \mathrm{Tcf}$ 以下の小規模ガス田であり, 特に東南アジ ア・太平洋地域においては，1 Tcf 以下のガス田数（開 発・生産中および未開発のものを含む）が1998年統計で 84.5\%を占める。そのため, 特にこの地域では, このよ うな小規模ガス田をいかに開発するかが今後の課題であ る。

このような状況において，天燃ガスの予想される急激 な需要の伸びに対し十分な供給量を確保していくことは 大きな課題である。大規模ガス田の開発のみならず，さ らなる探鉱開発技術の開発や効率化により確認埋蔵量を 増やすとともに, 天然ガス生産コストや輸送コストの削 減, 新たな市場の開拓, 新たな輸送手段や開発システム によるスタトランディッドガス（Stranded Gas）の開 発を行っていくことが必要になる。

また環境面からは, 現在約 3.6〜4.8 Tcf の天然ガス がフレアされており，これを削減するとともに有効利用 することが求められている。

さらに，長期的にはメタン八イドレートやコールベッ ドメタンなどの非在来型天然ガスの開発も, 今世紀の重 要な課題と考える。

\section{2 天然ガス消費・貿易の現状}

世界の天然ガス消費量の推移を見ると, 消費量は着実 に増加しており，一次エネルギーに占める天然ガスの割 合は各国において増加傾向にある。一方, 天然ガス消費 量の内訳を見てみると，依然自国ガスの消費量が多く， 2001年時点での天然ガス貿易量は, 消費量全体の $28 \%$ で ある。ただし最近の傾向としては，ロシアや米国など国 内ガス消費を主としていた国々におけるガス生産量の伸 びの鈍化に伴い，自国ガスの消費量はほぼ横ばいである のに対し，パイプラインあるいは LNG による貿易量が 増大してきている。

また，現在の世界の貿易量を見てみると，ガス取引の 主流はパイプラインによるあのであり, LNG 貿易は全 貿易量の約 $21 \%$ にすぎない。

現在の天然ガス貿易の流れを図 1 (上図) に示す。パ イプラインの場合は供給源と供給先が固定される。一方 LNG はどこへであ輸送はできるあのの, 輸送費が LNG コストに大きく影響することから，ある程度限定された 地域からの輸入となっている。この結果, 天然ガス貿易 は大きく欧州地域, 北米地域およびアジア・太平洋地域
の 3 つの貿易圏に分けられ, 欧州地域ではロシアおよび 北海からのパイプラインによる供給, 北米ではカナダか ら米国へのパイプラインによる供給, アジア・太平洋地 域では, 主に東南アジアや豪州から日本を中心とした極 東アジアへの LNG による供給が中心である。LNG の 需要と LNG 供給ポテンシャルのバランスを見ると, 今 後の需要の伸びに対し, 東南アジア・太平洋地域は LNG 供給過多, 大西洋地域は LNG 供給不足の傾向に ある。

\section{3 天然ガス需要見通し}

天然ガス需要の見通しについては，その豊富な埋蔵量 と環境への関心の高まり, クリーンなエネルギーとして の期待から, 今後急激に伸びると予想される。現在の世 界の一次エネルギー需要に占める天然ガスの割合は, 2000年時点で約 $23 \%$ あるが，BP は2010年までに世界 の一次エネルギー需要の $25 \%$ を天然ガスが占めると予想 している。またIEA は，2030年には天然ガスの消費量 が現在の 2 倍, 世界のエネルギー需要の $23 \%$ から $28 \% に$ 増加するとの見通しを示している。

天然ガス需要の伸びは, 主に発電を中心とした消費の 伸びであり, 新設する発電所の燃料の多くが天然ガスの 利用を計画していることに加え, 石炭などからの燃料転 換屯見込まれる。地域的には，人口増加が著しく急激な 経済発展の見込まれるインドや中国での需要が急激に拡

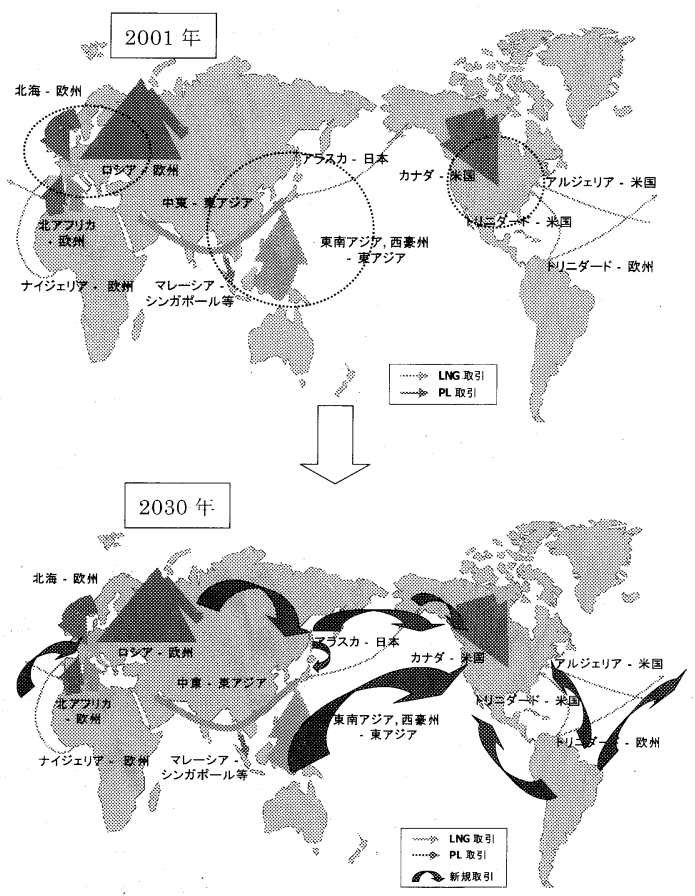

図 1 世界の天然ガス貿易の流れ 
大すると見込まれる。また，新規パイプラインの敷設， や LNG プロジェクトの立ち上げに伴う新規天然ガス市 場の開拓が見込まれる他, 天然ガスを転換にして液体燃 料とする（GTL/DME）ことによる, 新たな市場の拡 大が期待される。

\section{4 天然ガス取引の動向}

天然ガス取引は, 供給源の多様化や自由化の流れの中 で, 今後ますます競争が激化していくと予想される。従 来は分加ていた貿易圈も, 圈内の需給の差, 技術革新 に伴う LNG コストの低減化, 輸送手段の多様化（パイ プラインと LNG の競合) などにより, 長距離輸送, 地 域間の貿易量が増える傾向にある。国・地域間をまたが る貿易量に関しては，2030年には約 3 倍になるとの見通 しあ示されている。

貿易量の中であ，コスト低減に伴う競争力の向上を背 景に, 今後は LNG 取引が増大していくと思われる。 LNG 取引の増大は, 主にパイプライン輸送が主流であ る米国・欧州における LNG 需要の拡大によるものであ る。欧米では, 現在は域内生産, あるいは国際パイプラ インにより，比較的低コストで安定的に天然ガスを供給 しているあのの, 北海などの生産量が今後ピークを迎え 減退に向かう傾向にあることから，新規長距離パイプラ インや LNG による域外からの貿易依存度が上昇する傾 向にある。加えて既存パイプラインの主要な供給源であ るロシアや北米における生産が減退し, 生産コストが増 大する傾向にあることから，LNG 需要が拡大すると見 込まれる。

新たな地域・国での LNG プロジェクト, LNG 導入 の動き屯活発であり, サハリン（II）, 南米（ボリビア, ベネズエラ, ブラジル他), アフリカ（アンゴラ, エジ プト), アラスカ (LNG/PNG/GTL) などでの計画が 進められている。また市場としては，インドや中国に加
え, 米国市場の動向が重要となっている。特に米国西海 岸側は, 東南アジアやオセアニアの LNG に加え, 南 米, アラスカ, あるいはサ八リンからの LNG 供給の可 能性があり, パイプラインガスとの競合を含め, 今後の 天然ガス取引に大きな影響を及ぼすと予想される。

天然ガス供給地域としては, 中東やロシア（サハリ ン, 東シベリア）からの天然ガス供給が著しい伸びを示 すと予想される。これらの地域は豊富な天然がス埋蔵量 を有しており，大規模ガス田を中心に新たなプロジェク 卜が次々に計画されている。特に極東地域に対しては, サハリンプロジェクトからの LNG およびパイプライン による供給，ロシアや中国西域から太平洋沿岸向けの の, 西気東油パイプラインやコビクタガスパイプライン による供給の計画が進められている。サハリンIIについ ては, 最近東京電力㑣)および東京ガス㑣による LNG 購 入が決定したことから, 同 LNG プロジェクトが具体的 に動き出しており，さらに他の日本の電力・ガス会社 や，韓国への導入が計画されている。

図 1 (下図) に, 予想される2030年ごろの天然ガス貿 易の流れのイメージを示す。

当面の大規模ガス田を中心にした天然ガス取引に加 え，エリア的，中長期的には，フレアガスの有効利用 や，ストランディッドガスの開発の促進が見込まれる。

日本を含むアジア・太平洋地域の需給バランスを見る と, 天然ガス供給の主流である LNG の供給力は，しば らくは需要を上回る状況である。これに加え上述した口 シア，東シベリアなどからの長距離パイプラインによる 供給を考慮すれば，中国やインドを中心に予想されるエ ネルギー需要の増加にあ当面十分対応できる状態といえ る。

日本における天然ガスの需要と供給ポテンシャルを図 2 に示す。2008年ごろまでは, LNG 既存契約および新

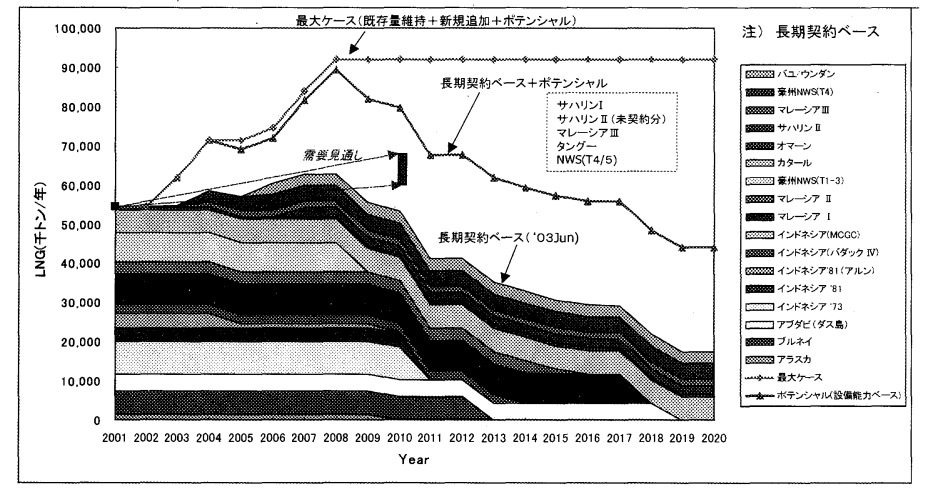

図2 日本への天然ガス供給ポテンシャル （注：サハリン I のガスも LNG に換算） 
規契約によりほぼ必要量の供給が確保されており,さら に今後の需要の伸びに対しても当面十分な供給ポテン シャルがある。今後日本へのパイプラインガスの導入, 北米西海岸での LNG 基地の新設の動向などが, 日本お よび極東地域の天然ガス需給動向に影響を与えるものと 考えられる。

\subsection{LNG 取引における変化}

LNG 取引においては，アジア太平洋地域を中心とし た供給過剰の状況を背景に，売り手市場から買い手市場 へと移行しており, 上流側の市場獲得競争が激化してい る。最近の LNG プロジェクトの中には, 供給能力全量 のコミットのないまま立ち上がるプロジェクトや, 従来 に比べ大幅に安い価格での契約も見られるようになって きている。

下流側でも需要の中心であった日本などの電力・ガス 需要の鈍化, 電力などの自由化に伴う新規参入の促進な ぞにより, LNG 取引にも弾力性やコスト削減努力が求 められており, 従来型の長期取引契約, テイクオアペイ といった契約から, 短期契約やスポット取引の増加や, FOB 契約, 仕向け地変更が可能な柔軟性のある契約と いった新たな契約形態も見られるようになってきてい る。またそのような中で, 上流企業が, 中流や下流へ, あるいは下流の会社が上流へ参画する例も見られ，今後 さらに増加するものと思われる。

\section{6 天然ガスの新たなチャレンジ}

天然ガスの需要を予想通りに伸ばしかつ安定的に天然 ガスを供給していくためには, 以下のようなチャレンジ が必要であると考える。

\subsection{1 発電における競争力の向上}

今後新規に予定されている発電所の燃料の多くは天然 ガスが計画されているが, 確実に需要を伸ばしていくた めには, 引き続き LNG コストの低減による他燃料との 競争力の向上が求められる。

\subsection{2 競争と調和の両立}

パイプラインを中心としていた欧州・米国市場におい て, LNG の導入が図られて抢り, パイプラインガスと LNG との競合や供給源の多様化が加速すると見られる。 さらにガス・電力の自由化や LNG 契約の変化に伴い, 競争が激化している。このような中, 依然, パイプライ ンプロジェクトあ LNG プロジェクトも多額の投資が必 要であることから, 競争ある市場の中で確実にこれらプ ロジェクトを立ち上げ，安定的にガスを供給していくこ とが必要であり，そのためには供給側と需要側とがリス クと利益をシェアしていく体制, 競争と協力, 情報の交 換を行いながら協調していくことなどが求められ，その ような新しい天然ガスチェーンの構築が必要になると考
える。

\subsection{3 技術開発}

以下のような技術開発が必要である。

・コスト削減による競争力のアップ

・生産量減退, 生産コス卜増大への対策

-GTL や DME 技術の開発による需要の拡大

また長期的に，以下のような技術開発に取り組む必要 がある。

・ストランディッドガスの開発（遠距離, 大水深, 大 深度他)

・非在来型天然ガスの開発

$\bullet \mathrm{CO}_{2}$ 排出削減

\subsection{4 投資力の増強}

需要増や市場の変化に対応するために必要な投資額は 莫大であり，LNG 投資，パイプライン投資を支える主 要エネルギー産業の成長・連携が重要である。

\section{GTL プロジェクトの動向と GTL 製品の市場性}

\subsection{GTL プロジェクトの現状}

近年, 天然ガス有効利用の新たな可能性として，天然 ガスから液体燃料を製造する GTL 技術が注目されてい る。同技術は，天然ガスから合成ガスなどを経由して， フィッシャー・トロプシュ合成（FT 合成）, 水素化分 解などにより，最終的に中間留分・ワックスなどの石油 製品,メタノール，ジメチルエーテル（DME）などを 製造する技術である。

FT 合成法によるGTL の商業プラントは, 現在 Sasol 社（南アフリカ; サソールブルグ, セクンダ), PetroSA 社（旧 Mossgas 社）（南アフリカ；モッスル ベイ), および Shell 社（マレーシア；ビンッル）の 4 ケ所で稼動中であり，このうち PetroSA 社と Shell 社 の 2 つの GTL プラントは天然ガスを，それ以外は石炭 を原料としている。

南アフリカのプロジェクトは，いずれあアパルトへイ ト下での石油の禁輸政策という特殊環境下で始められた あのであり，また Shell 社のビンッルプロジェクトも， パイロットプラント的要素が強く，いずれも国際的競争 力のある商業プラントとはいいがたく, 本格的な商業化 に向けた向けて継続的に技術開発が進められている。

DME については，燃料としての製造・利用実績はな く，化成品用として限られた量の製造・使用がなされて いるに過ぎない。

\section{2 現在の GTL (FT) 製品の市場}

現在生産されている FT 製品の詳細な販売先や市場は 公表されていないが, 量的にも限られていること, 既存 
の石油製品に比べて高品位であることから，既存市場に 問題なく受け入れられている。

\subsubsection{Shell 社}

ビンッルプラントの GTL 生産量は $12,500 \mathrm{bpd}$ であ り, 中間留分 (Gasoil, Kerosene), ナフサ, $\mathrm{N}$ パラ フィン, 潤滑油, ワックス他の FT 製品を生産し，アジ ア太平洋地域を中心に, 欧州, 北南米などで販売してい る。2001年11月には，日本においても鎌倉地区で約 $4,500 \mathrm{~m}^{3}$ の FT 灯油の販売が一般消費者向けに試験的 に行われた。また，2002年初旬よりタイのバンコクで石 油製品とFT製品をブレンドした “Pura” 軽油の販売が 行われている。

\subsubsection{Sasol 社}

生産物の約 $70 \%$ は燃料製品, 約 $30 \%$ は化学製品であ る。燃料製品は，主に南アフリカで石油製品とブレンド して販売されている。軽油以外にも, ジェット燃料とし て石油系ジェット燃料と混合してヨハネスブルグ空港で 使用されている。化学製品は国外を中心に販売してお り，200以上の化学製品を約 90 力国で販売している。

\subsubsection{PetroSA 社}

ガソリン，軽油，灯油，LPG，燃料油などを主に南 アフリカ市場で販売している。一部の製品は，欧州，米 国やアジア太平洋地域で販売されている。

\subsection{GTL 商業化に向けた動き}

GTL/DME の商業化にあたっては，製造コストが高 いことからこれまでは特殊環境下でしかプロジェクトが 成立しなかったが，1990年代以降，新しい反応器の開 発，新しい触媒の開発などにより製造コストの削減が図 られ，商業化の可能性が現実のあのとなってきた。また 天然ガスの有効利用や環境意識の高まり，厳しくなる軽 油の硫黄規制への対応，フレアガスの削減・有効利用と いった観点から，GTL 合成油特有のクリーンな点など GTL 製品への期待が高まってきた。
GTL が本格的に商業化されれば，天然ガスおよび天 然ガス系燃料の需要増につながるとともに，原油同様の 輸送性を持つことから，天然ガスにとっては新たな地域 への市場の拡大，新たな市場の確立につながると期待さ れる。また，エネルギー全体としては，中東依存度の高 い石油の供給源の多角化，石油依存度の低下，環境対策 に貢献すると考えられる。このため, 多くの商業化プロ ジェクトの検討が行われるとともに，多くの研究開発 が，パイロットプラントやデモンストレーションプラン 卜段階へと移行してきている。図 3 に GTL プラントコ ストの推移を示す。

DME については，燃料としての使用実績がないが, 性状が LPG に類似していることから LPG 代替燃料と して期待されている他，発電用燃料，軽油代替，あるい は燃料電池用燃料としても期待されている。DME の燃 料としての利用は, 以前は BP 社 (インド), 欧州（コ ペンハーゲン）が積極的であったが，現在では日本企業 が豪州，イランなどでプロジェクト化し，日本への燃料 としての導入することを最む積極的に検討している。特 に，日本企業を中心とした 2 つのグループ（日本 DME (株抢よび DME インターナショナル(㑣) が，2006年から の日本への導入を目指した商業化調查を実施している。

現在 GTL/DME 商業化プラントとしては，17ケ国で 35以上のプロジェクトが計画・検討されており，早いも のでは2005年後半からの生産開始を目指している。

主なプロジェクトを図 4 に示す。これらのプロジェク 卜の内, 先行しているのは大規模ガス田を有するカター ル，イラン，オーストラリア，厳しくフレアガスを規制 するナイジェリアなどでのプロジェクトである。このう ち, Sasol 社/カタール国営石油会社 (QP) のカタール プロジェクト（生産量34,000 bpd）ならびに Sasol Chevron 社/ナイジェリア国営石油会社 (NNPC) のナ イジェリアプロジェクト（フレアしている随伴ガスを利

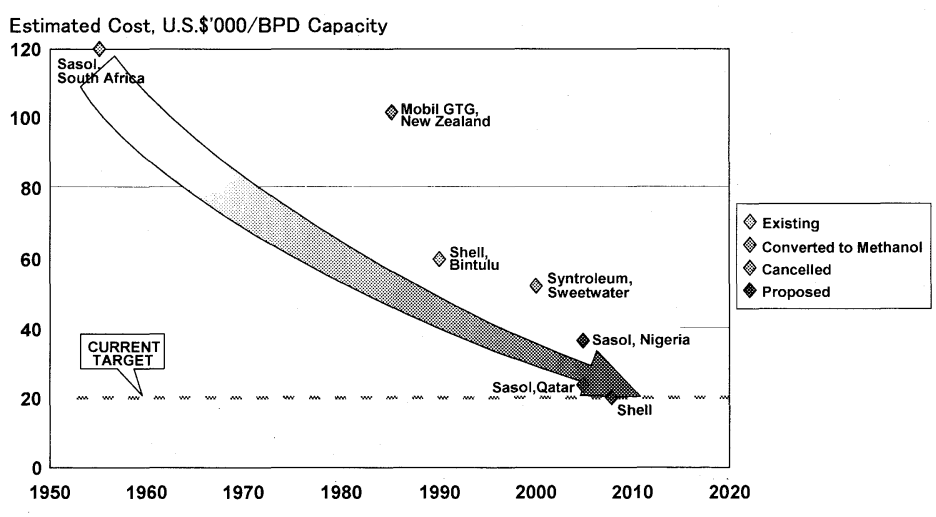

図 3 GTL プラントコストの推移 


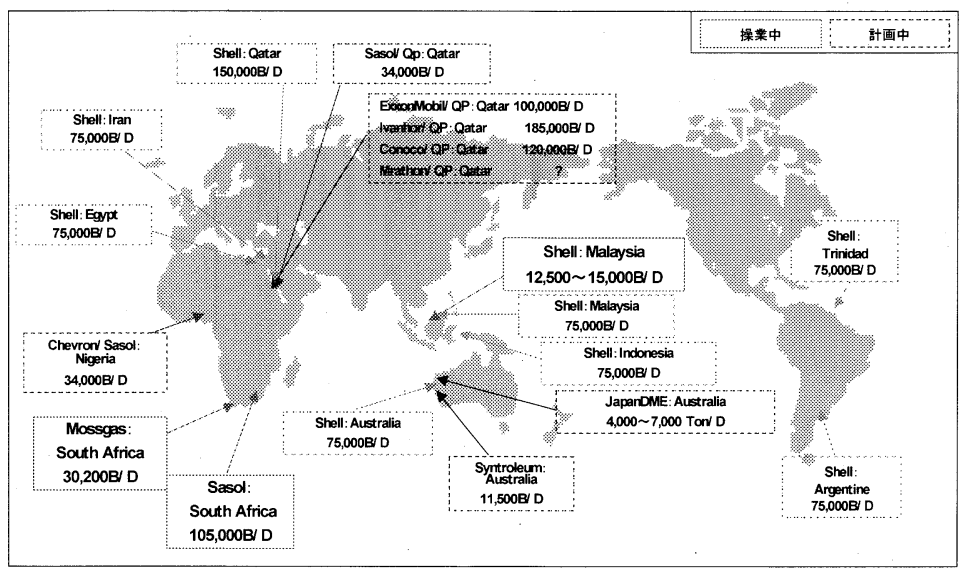

図 4 GTL/DME プロジェクト

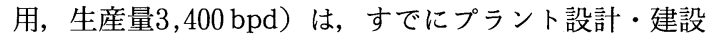
に向けて動いている。また, Shell 社はマレーシアでの 実績を踏まえ，世界 8 ケ国で75,000 bpd 規模の GTL プ ロジェクトを検討している。

\subsection{GTL 生産ポテンシャル}

現在稼動中ならびに計画中の GTL プロジェクトの位 置及び生産能力を図 5 に示す。各プロジェクトの規模 は，5〜185 Mbpd とさまざまであるが，スケールメ リットを生かして開発および操業コスト単価を削減する ために，より大きなプラントを目指す傾向にある。これ ら GTL プロジェクトの生産能力をすべて合計すると, 2010年で約1.8MMbpd であり，それに必要とするガス 量は約1,800 MMscfd である。

商業プロジェクト成立に有利な条件としては, 安価な ガス, インフラが整備している地域, 必要量のガスの供 給安定性, 産ガス国・需要国の支援が得られることなど が挙げられる。また技術的には，商業規模までのスケー ルアップおよび技術リスクの克服であり，これらによる 製造コストのさらなる削減が必要である。現在 GTL プ ラントコストはUS $\$ 30,000 / \mathrm{bpd}$ 前後まで削減されて きているものの，ほとんどの商業化プロジェクトが，成 立の条件として US $\$ 20,000 / \mathrm{bpd}$ を目標としている。

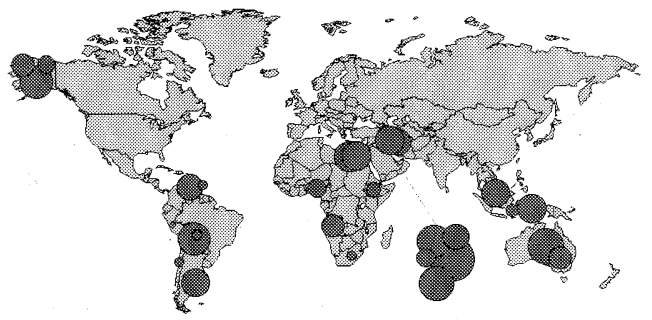

図 5 GTL生産ポテンシャル
この他, 市場の確保, ファイナンスの確保が重要であ り，またプロジェクト立ち上げのタイミングが，GTL 製品の既存市場への導入, プレミアム価格の確保の点 で，非常に重要となる。このような条件を考慮した場 合, カタールでの大規模ガス田による GTL プロジェク トが最初の商業化プロジェクトとなる可能性が最も高 い。GTL は，LNG プロジェクトが困難な中小規模ガス 田や，リモートガス田にも適用可能と期待されている が，これらへの適用にはまだ時間がかかると思われる。

GTL の生産能力予测を図 6 に示す。上述した GTL 商業化プロジェクトの成立の可能性を考慮した Most Likely ケースでは，2010年時点での GTL 供給可能量は 約 $980 \mathrm{Mbpd}$ と評価された。

\subsection{GTL 製品の市場性}

GTL 製品の市場としては，軽油，灯油，ナフサ，Nパラフィン，潤滑油などの市場が挙げられ，これら市場 への導入可能性について検討した。DMEについては, 既存の燃料市場がないため，特に競合すると考えられる

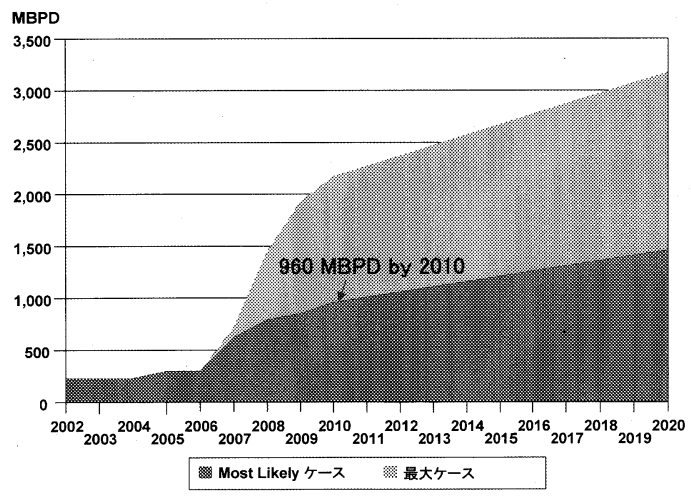

図 6 GTL生産能力予測（～2020年） 
LPG 市場との比較を行った。

\subsection{1 軽油 (Ultra Low Sulfur Diesel)}

多くの GTL プロジェクトが主に生産を計画している のは軽油である。FT軽油は低硫黄であり, 軽油の硫黄 分規制が強まりつつあるなかで，アップグレード用のブ レンド基材として注目されている。

軽油の需要は著しい伸びを示しており，2020年までに 需要が約 $50 \%$ 増加すると見込まれている。図 7 に，2020 年までの世界における軽油の需要予測と, FT 軽油の生 産量予測を示す。FT 軽油の生産見込みは, 2010年では 軽油需要全体の約 $5 \%$ ，増加分の $20 \sim 25 \%$ に相当する。 軽油市場は，GTL生産ポテンシャルに対し十分な規模 があり, また今後需要の増加も見込まれることから最も 有望な GTL 製品市場であり，市場への導入は十分可能 であると考えられる。硫黄分規制に加えて，芳香族分や セタン化の規制が強化されている欧州やカリフォルニア では，FT 軽油は規定外石油製品をアップグレード（硫 黄分, 芳香族分, セタン価）するための非常に有力なブ レンド基材であり，他国すこれに追随して規制を強化す る場合には，需要はさらに高まると考えられる。また， 十分低価格化が図られれば，石油製品代替（量的）ブレ ンド基材としてあ期待できる。

FT 軽油の夕ーゲット市場をまとめると，ブレンド基 材としての利用が有力であり, 米国, 特に規制の厳しい カリフォルニアにおいて，また中間留分を多量に輸入し ている欧州，特にフランス，ドイッ，次いで英国，スペ インなど，アジア太平洋地域では日本，オーストラリ ア，中国，インドなどがポテンシャル市場と考える。ま た，ニッチ市場として，政府公用車，都市交通機関，あ るいは社用車用の燃料としてへの使用が期待できる。

一方 FT 軽油の市場性の課題としては，以下のような あのが挙げられる。

・低比重, 低膨潤性といった問題があり, 現在の比重

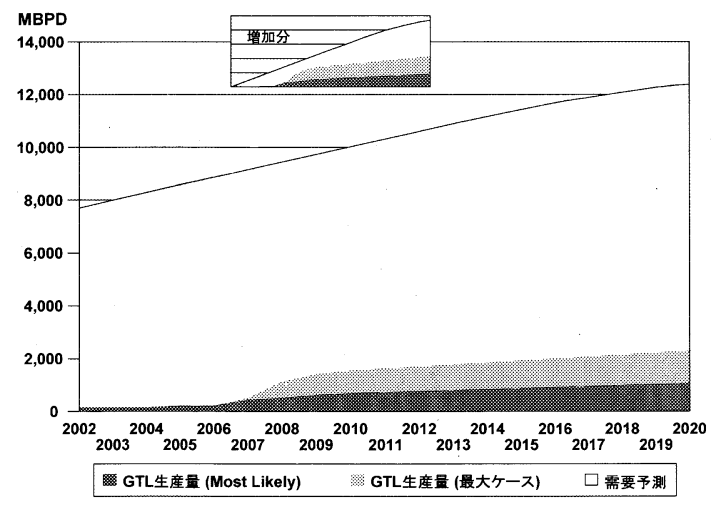

図 7 世界の軽油需要予測と GTL 生産ポテンシャル
仕様に適合するためには，ブレンドする場合にも混 合可能な量が限られる。また，純粋な FT 軽油の利 用には，現在のディーゼルエンジンの改良や新たな エンジンの開発が必要となる。

・ FT 軽油の価格については, 低硫黄軽油としての価 格の上乗せはありえるものの，同品位の石油系低硫 黄軽油以上に, FT 軽油であることによるプレミア ムはあまり期待できない。

-石油製品との競合：各国の硫黄規制に適合するた め，石油系軽油の低硫黄化む精製会社により検討さ れており，従来コスト的に困難と思われた硫黄分50 ppm 以下あるいは $10 \mathrm{ppm}$ への早期対応，コス卜低 減化の対応がなされつつあり，FT 軽油の導入の夕 イミング，すなわち，精製会社が低硫黄化のために 製油所の脱硫装置への設備投資を本格化する前に FT 軽油の導入することができるか否かが重要と なってくる。早期導入を図る観点からは，エリアが 限られインセンティブが期待できる社用車，官庁 車，都市交通などを対象にした導入を図ることが有 効と思われる。

・また，自動車用燃料としては，CNG，LPG といっ た他のクリーン燃料との競合あ考慮する必要があ る。

\subsection{2 ナフサ (Naphtha)}

ナフサは，エチレン用の水蒸気分解 (Steam Cracking）原料としての市場があり, 特にアジア太平洋地域 で急激な需要の増加が見られる。価格についても，FT ナフサは低比重であることによる価格のディスカウント はあるあのの，エチレン留分が多いことから，それに伴 うプレミアムが期待できる。

図 8 に，2020年までのアジア太平洋地域のナフサの需 要予測と, FT ナフサの生産量予測を示す。2010年で FT ナフサのポテンシャルは, アジア太平洋地域のナフ

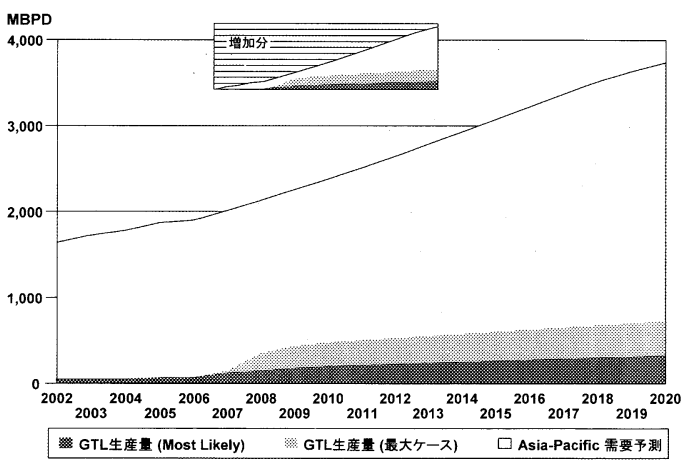

図 8 アジア太平洋地域におけるナフサ需要予測と GTL生産ポテンシャル 
サの需要増加分の約 $20 \%$ 程度であり，ナフサ市場は，軽 油と同様に量的には FT 製品にとって市場規模も十分 で，さらにアジア太平洋地域で急激な伸びが期待でき， プレミアムも期待できることから，FT 製品としては最 あ有望な市場であり，価格しだいでほとんど市場への導 入は問題ないと判断される。

FT ナフサの主要なターゲット市場はアジア太平洋地 域であり，特に急激な経済成長著しい中国，インド，次 いで日本，韓国などが有望である。また将来的には，燃 料電池用燃料としての可能性がある。

\subsection{3 灯油 (Kerosene)}

FT 灯油は，ジェット燃料用ブレンド基材が主要な市 場として考えられ，欧州，米国などで十分な規模の市場 がある。ただし，9.11の影響による需要の伸びの鈍化が 問題であり，また，ジェット燃料としての仕様基準にあ わせるためには，現状混合可能なのは最大約 $50 \%$ であ る。

アジア太平洋地域では, ジェット燃料より，料理用お よび暖房用燃料としての需要が大きい。ただし供給は過 剩気味であり，また純粋な FT 灯油の利用にあたって は，仕様規制に比べ低比重であること，膨潤性が低いこ とが課題として挙げられる。

\subsubsection{N-パラフィン（N-paraffins）}

図 9 に，2020年までの世界における N-パラフィンの 需要予測と, FT N-パラフィンの生産量予測を示す。

FT N-パラフィンは, 従来の製法に比べ生産コスト が安くなる可能性があり，また高価值で品質の良い点か ら, 十分石油製品と競合できると考えられる。しかし， 市場の規模が小さいのが問題であり，需要の増加予測量 以上の供給ポテンシャルがあり，供給過多になる可能性 がある。N-パラフィンの増加分は，ほぼ 1 つの GTL プ ラント供給能力程度の市場しか期待できない。このた

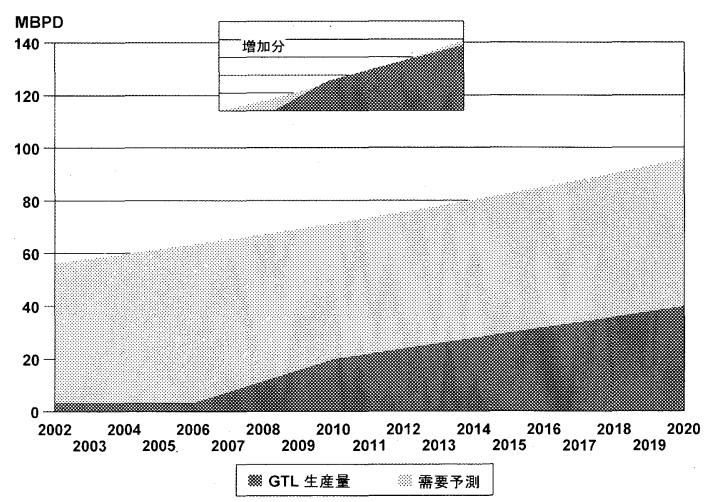

図 9 世界の $\mathrm{N}$-パラフィン需要予測とGTL生産ポ テンシャル
め，早期 GTL プラントの立ち上げ・導入が重要であ り，いったん充足されると，さらなるプロジェクトの立 ち上げは期待できない。N-パラフィンのターゲット市 場として可能性があるのは, アジア太平洋地域であり， 同地域での LAB (Linear Alkyl Benzene) の需要の伸 びがキーとなる。

\subsection{5 潤滑油（Lube Oils）}

GTL プラントからは, 高品位の潤滑油（Group III, VI, Poly-alpha Olefins (PAOs)) が製造可能である。 従来の製法に比べ生産コストが安くなる可能性があり, プレミアムも期待できる。

図10に，2020年までの世界における潤滑油の需要予測 と，GTLによる潤滑油の生産量予測を示す。市場とし ては，欧州，米国などが挙げられるが，市場が小さいの が大問題であり，N-パラフィンと同様に需要の増加分 以上の GTL生産ポテンシャルがある。

図11に，潤滑油の各グループ別市場の規模と，GTL の主なプロジェクトである Exxon Mobil 社のカタール プロジェクトの生産ポテンシャル量を示す。高品位の市 場（図にはGroup III とPAO を示す）は非常に小さい市

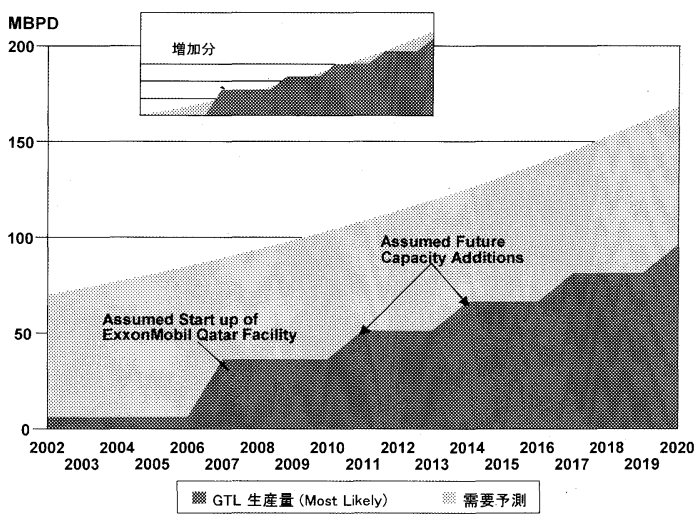

図 10 世界の高品位潤滑油需要予測と GTL 生産 ポテンシャル

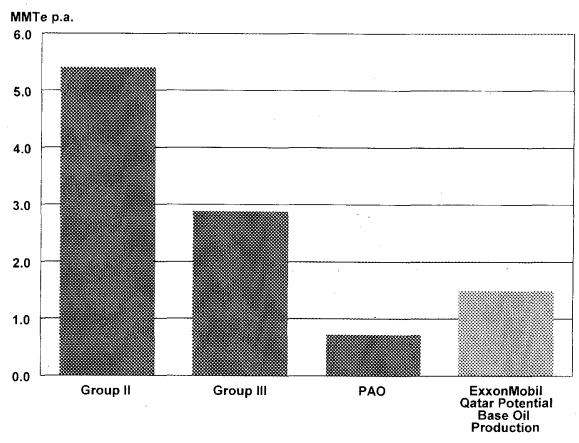

図 11 潤滑油市場と GTL 製品供給可能量 
場であり，現在の PAO市場は，同プロジェクトのポテ ンシャルより小さいことが分かる。このため，石油製品 との間だけではなく GTL プロジェクト間で競合するこ とになり，早期立ち上げがキーとなる。

一方，低品位の潤滑油市場（図には Group II を示す） は，高品位より市場規模が大きいものの，GTL 製品と して高品位である利点，プレミアムを生かすことができ ないため，経済的に魅力的な市場とはいいがたい。

\subsubsection{DME (Dimethyl Ether): $\mathrm{CH}_{3} \mathrm{OCH}_{3}$}

DME は，現在エアゾール用噴射剤（塗料，農薬，化 精品用）などの化学製品として利用されているが，その

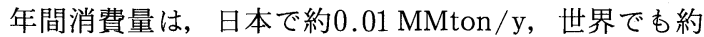
$0.15 \mathrm{MMton} / \mathrm{y}$ に過ぎない。現在計画されている $\mathrm{DME}$ プラントの規模は，0.8〜2.9 MMton $/ \mathrm{y}$ であることか ら，燃料としての新たな市場の確立が必要である。

図12に, アジア太平洋地域における LPG 需要見通 し，日本における LPG 需要見通しと，DME 生産ポテ ンシャルを示す。競合する LPG の市場規模は十分あ り, 需要の伸びあ期待できる。LPG より安価であるこ とから，既存の LPG 利用からの切り替えによる市場の 確保の可能性はあり，また，燃焼がクリーンであるとい う特性を活かして発電用などの石油系燃料からの切り替 え, 軽油代替としての利用, 燃料電池用燃料としての利 用も考えられ，市場規模は大きいと考える。ただ一方で 燃料としての実績がないことから，燃料としての安全性 の確認, 仕様基準整備, インフラ整備などの環境を整え ることが必要である他, 利用技術の開発や生産コスト低 減などが求められる。

日本は，LPG 代替，発電用燃料，軽油代替として積 極的な導入が検討されており，2006年より $1.4 \sim 2.4$ MMton/y の DME 燃料の導入を計画している。また将 来的には, 燃料電池用の燃料として需要の伸びが期待で

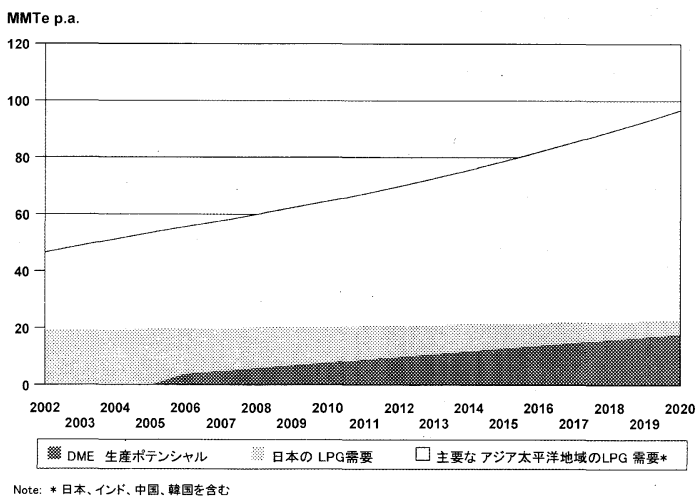

図 12 アジア太平洋地域における LPG 需要予測 と DME 生産ポテンシャル
きる。いったん日本で導入されれば， LPG 需要の伸び の著しいインド，中国，韓国が同様に追随する可能性が あることから，日本への導入がキーとなる。

ただし，2006年からの日本への導入はやや楽観的と判 断され，導入時には何らかのインセンティブが必要と思 われる。また，燃料としての実績がないなか，プロジェ クト立ち上げのために必要な規模の市場を確保するため には，大口のユーザーの確保が重要であり，とりあえず は発電所用燃料としての利用，あるいはインセンティブ が期待できる都市交通用燃料としての導入が有効である と考える。

\subsection{GTL の課題}

\subsubsection{GTL 合成油}

技術的には，現状よりさらなる GTL の開発・設備コ ストの削減を行い，ターゲットとしているUS $\$ 20,000$ bpd を達成すること，技術的な信頼度の向上を図るこ とが必要である。コスト削減にあたっては，最あコスト のかかる合成ガス生産コストの削減，反応器などのス ケールアップが重要である。当面はブレンド基材として の使用になる之思われるが，将来的に純粋な GTL 合成 油の利用のためには，既存のディーゼルエンジンなどの 機器の改良や新規開発が必要である。

この他商業化プロジェクトの立ち上げには, 安定供給 や，ファイナンスの確保が課題であり，また立ち上げの タイミングあ重要である。さらに，石油製品に加え，

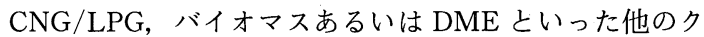
リーン燃料との競争力の向上が課題である。

\subsubsection{DME の課題}

DME の燃料としての導入にあたっては, DME 生産 技術の確立，使用環境の整備による早期導入を行い，市 場を確立することが不可欠である。

技術的課題としては，DME 製造技術はすでに確立さ れているあのの，燃料としての利用にあたっては，効率 化，プラントのスケールアップ，コスト低減による経済 性の確保が必要であるととあに，シール性の確保， DME 用エンジンの開発などの利用技術の開発も課題で ある。また，燃料としての使用環境としては，燃料とし ての仕様の設定, 使用基準の確立, 安全性の確認, 法規 制の整備などを行う必要がある。

\section{4. まとめ}

天然ガスの需要は，今後急激に増加すると予測され， 長距離輸送，特に LNG 貿易量が増大する傾向にある。 上流側の市場獲得競争，他燃料之の競争が激化するな か，いかに安定的に天然ガスを供給していくかが大きな 課題であり，輸送コストや LNG コストの削減による競 
争力のアップ, 技術開発による生産コストの削減, 関連 企業の投資力の強化が必要である。また, 多様化や自由 化による競争と安定供給の両立のために, 供給側と需要 側とがリスクと利益をシェアするような新しい取引の仕 組みの構築が求められる。また, プロジェクトの立ち上 げのタイミングが, 市場確保にとって非常に重要とな る。

GTL/DME については, 天然ガスの新たな有効利用 形態・可能性として大いに期待され，特に軽油やナフサ 市場がターゲットとして有望である。しかし，目標とし ているコスト削減を達成するととあに, DME に関して は使用環境を整えることが必要であり,さらに適切な夕 イミングで市場への導入を図ることができれば，十分な 市場を確保できる可能性がある。

\section{SI 単位換算係数}

$$
\begin{array}{cc}
\mathrm{bbl} \times 1.589873 & \mathrm{E}-01=\mathrm{m}^{3} \\
\mathrm{Tcf} \times 2.831685 & \mathrm{E}+10=\mathrm{m}^{3} \\
\mathrm{scf} \times 2.831685 & \mathrm{E}-02=\mathrm{m}^{3} \\
\text { 参 考 } \text { 文 献 }
\end{array}
$$

BP, 2002 : BP Statistical Review of World Energy June 2002.

石油公団, 1998 : 平成10年度石油公団調査「アジア太平 洋地域の中小規模の既発見未開発田調查（II）（委託 先，日本オイルエンジニアリング(森)」.

石油公団, 2002 ：平成14年度石油公団調查「Marketability of GTL Products (委託先：GCA 社)」. 